\title{
Patterns and causes of conversion of smallholder rubber plantation to oil palm (case in Batik Nau sub district, Bengkulu Utara Regency)
}

\author{
Afrizon*, Andi Ishak, Emlan Fauzi, Miswarti, Siti Rosmanah, andYudi Sastro \\ Bengkulu Assessment Institute for Agricultural Technology, IAARD, Bengkulu, Indonesia
}

\begin{abstract}
Batik Nau Subdistrict has the largest rubber plantation in North Bengkulu Regency, namely 3,779 hectares, but much of it has been converted to oil palm plantation. The conversion occurred quite massively, namely 393 hectares or 10.4 percent in 2019 . This study aims to determine the patterns and causes of the conversion of smallholder rubber to oil palm in the Batik Nau Subdistrict. The research was conducted in three rubber production center villages in Batik Nau Subdistrict from January to March 2021 through in-depth interviews with 10 key informants. The data extracted relates to the patterns and factors causing the conversion of rubber to oil palm. In addition, secondary data collection and field observations were also carried out to confirm the results of the interviews. The data were processed descriptively. The results showed that there were two conversion patterns, namely direct conversion and gradual conversion. The main causes of conversions are low rubber prices and inefficient use of labor. In developing rubber farming the people must pay attention to the availability of labor in the family.
\end{abstract}

\section{Introduction}

Land conversion is a change in the function of part or all of the land area from its original function to another function. Land conversion is a specific change from use for agriculture to non-agriculture $[1,2]$. Conversions occur a lot in agricultural land, for example, the conversion of food crops into plantations [2,3], plantation crops to food crops [4], plantation crops to horticultural crops [5], and plantation crops to plantation crops [6].

The phenomenon of the conversion of rubber plants has occurred in several regions in Sumatra. For example, in Jambi Province, the decline in the area of smallholder rubber plantations was due to conversion to oil palm covering an area of 3,429 hectares[8], Padang Lawas Regency, North Sumatra 94.6\%, Kuantan Singingi Regency, Riau Province 12.5\%. The conversion pattern of rubber land to oil palm can be divided into 2 types, namely: 1) gradually/gradually occurring sporadically/scattered, carried out by individuals, 2) simultaneously (instant) which is massive, occurs in one broad and concentrated stretch [3]. This is due to unstable price fluctuations, a tendency to decline, low quality and productivity of rubber plants $[7,8]$.

* Corresponding author:afrizon41ok@gmail.com 
Conversion of rubber to oil palm also occurred in Bengkulu Province which had a rubber plantation area of 102,867 hectares with production centers in North Bengkulu Regency covering 30,319.50 ha (29.47\%). In the last 5 years, the area of rubber plantations in Bengkulu Province decreased by 16,118 hectares (13.8 percent), while the area of oil palm plantations increased by 16,360 hectares ( 8.5 percent). This indicates that there has been a conversion of rubber land to oil palm in Bengkulu Province [9].

Batik Nau Subdistrict is a rubber production center in North Bengkulu Regency. Conversion of rubber to oil palm is found in thus subdistrict. Based on information from subdistrict plantation officers, the conversion of rubber to oil palm in Batik Nau Subdistrict has occurred in the last 5 years. Therefore, this research aims to find out the patterns and causes of the conversion of smallholder rubber to oil palm in Batik Nau Subdistrict, North Bengkulu Regency.

\section{Research methods}

The study was conducted in Batik Nau Subdistrict from January to March 2021. The choice of Batik Nau Subdistrict was because it has a large conversion area of rubber plantations in Bengkulu Province, which reached 280 hectares in 2019 especially in 3 villages namely Air Manganyau, Maninjau, and Samban Jaya (Table 1) [10].

Table 1. Total area and rubber plantations of villages in Batik Nau Subdistrict in 2020 [11]

\begin{tabular}{|c|c|c|c|c|}
\hline \multirow{2}{*}{ No. } & \multirow{2}{*}{ Village } & Area $\left(\mathrm{km}^{2}\right)$ & Area & $\begin{array}{c}\text { Rubber plantations (ha)* } \\
\text { Converted plantations in } \\
2019\end{array}$ \\
\cline { 4 - 5 } & & & & 0 \\
\hline 1. & Serangai & 8.56 & 25 & 5 \\
\hline 2. & Selolong & 11.99 & 85 & 10 \\
\hline 3. & Air Lakok & 34.62 & 330 & 5,5 \\
\hline 4. & Bintunan & 9.70 & 54.5 & 0 \\
\hline 5. & SukaMarga & 11.99 & 45 & 15 \\
\hline 6. & Batik Nau & 11.98 & 125 & 20 \\
\hline 7. & Pagar Ruyung & 9.47 & 285 & 12 \\
\hline 8. & Durian Amparan & 9.16 & 290 & 15 \\
\hline 9. & Taba Kelintang & 8.56 & 190.5 & 10,5 \\
\hline 10. & UlakTanding & 12.79 & 105 & 5 \\
\hline 11. & Sekiau & 13.70 & 81 & 15 \\
\hline 12. & SeberangTunggal & 11.22 & 145 & 100 \\
\hline 13. & Air Manganyau & 7.88 & 575.5 & 80 \\
\hline 14. & Maninjau & 7.24 & 501 & 100 \\
\hline 15. & Samban Jaya & 6.28 & 548.5 & \\
\hline
\end{tabular}

* Data source: North Bengkulu Regency Plantation Office, 2020

Data collection was carried out by interviewing key informants consisting of subdistrict plantation officers, village officials, heads of farmer groups, and rubber farmers who had converted their land from rubber to oil palm. The information extracted in the interviews covered the patterns and causes of the conversion of rubber to oil palm. Secondary data and field observations were used to confirm the results of the interviews. Data analysis using interactive methods, namely data collection, data presentation, data reduction, and concluding are carried out interactively which is supported by confirmation of the results of interviews with each key informant supported by the results of field observations and secondary data. 


\section{Results and discussion}

\subsection{Research area conditions}

Batik Nau Subdistrict is one of 19 subdistricts in the North Bengkulu Regency. The subdistrict capital is located in Batik Nau Village. The subdistrict area is $175.14 \mathrm{~km} 2$ consisting of 15 villages and is located between $101^{\circ} 58^{\prime} 388^{\prime} \mathrm{E}$ and $3^{\circ} 28-216^{\prime} \mathrm{S}$ (Figure 1).

Batik Nau Subdistrict is bordered by Giri Mulya and Padang Jaya Subdistricts to the north, the Indian Ocean to the south, Lais Subdistrict to the east, and Ketahun Subdistrict to the west. The topography of the Batik Nau Subdistrict is hilly with an altitude between 0-100 meters above sea level with a fairly high rainfall between 1,000-2,000 mm/year. This lowland dryland agroecosystem with a wet climate makes Batik Nau Subdistrict suitable for rubber development [11].

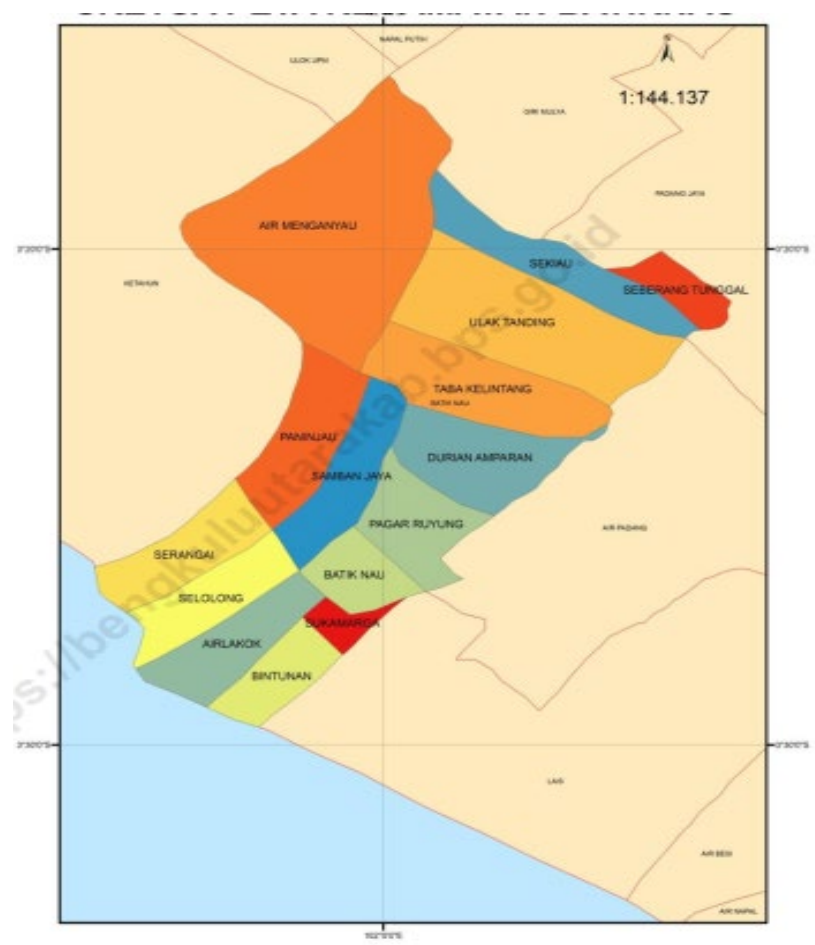

Fig. 1. Map of Batik Nau Subdistrict [11]

Of the 15 villages in Batik Nau, 3 villages have the largest rubber plantations, namely Air Manganyau, Maninjau, and Samban Jaya Villages (Figure 2). In the period 2019-2020, there was a significant decrease in the area of rubber plantations. In 2019 the area was 3779 ha and in 2020 was 3386 ha There was a decrease of 393 ha [10]. The application of rubber cultivation technology in the Batik Nau Subdistrict is still traditionally carried out fromgeneration to generation and this area wasformerly a plasma fromNusantara Plantation 7 Ltd. (PIR - PTPN 7). 


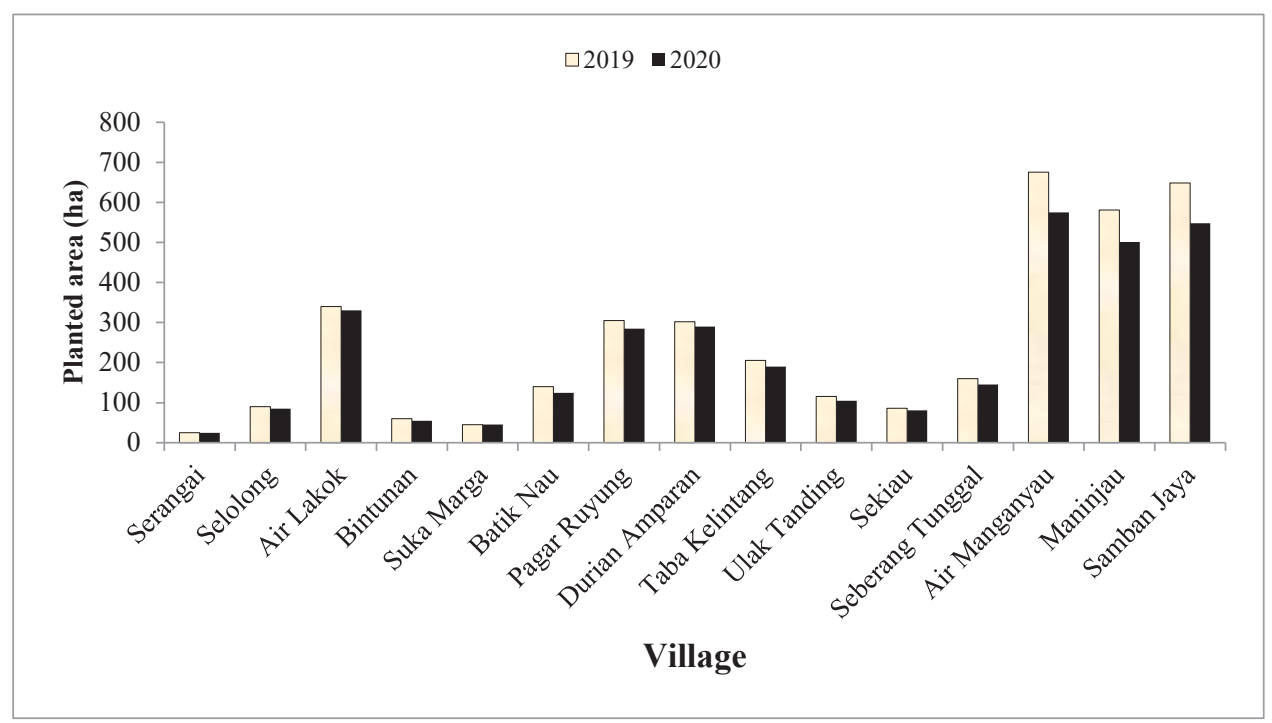

Source: North Bengkulu Regency Plantation Office, 2020

Fig.2. Comparison of rubber plantation area per village in Batik Nau Subdistrict, 2019-2020

\subsection{Application of rubber cultivation technology}

The application of appropriate cultivation techniques is necessary to accelerate the maturity period of tapping and optimize plant productivity. These efforts can be done through soil cultivation, timely planting, use of large planting holes, proper and balanced fertilization, and disease control.

The application of rubber cultivation technology in Batik Nau Subdistrict is still traditional. Some farmers still use local clones that come from seeds, most of them have used superior clones (since the existence of PIR-PTPN). According to [12], one of the causes of low rubber productivity in plantations is generally due to the inadequate application of the management of recommended clones. Therefore, to optimize the productivity of rubber plants, it can be pursued by selecting high-yielding clones, adjusting the composition of clones in the garden, and placing clones in the appropriate agro-ecosystem. Spacing that is not according to recommendations and maintenance that is not optimal and the tapping system is not according to recommendations. Bad seeds can reduce production by up to $60 \%$. This factor is one of the causes of low rubber productivity in this subdistrict. The application of rubber cultivation technology in Batik Nau Sub district is presented in Table 2. 
Table 2. Application of rubber cultivation technology in Batik Nau sub district

\begin{tabular}{|c|c|c|c|}
\hline No. & Technology components & Description & Recommendation* \\
\hline 1 & Use of clones & PB 260 clone andseedling & Superior clone PB 260 \\
\hline 2 & Planting space & Irregular & $4 \times 5$ meter \\
\hline 3 & Population & 700 plants/ha & 500 plants/ha \\
\hline 4 & Use of fertilizers & Do not use fertilizers & $\begin{array}{c}350 \mathrm{~g} \text { urea, } 200 \mathrm{~g} \text { SP 36,and } \\
300 \mathrm{~g} \mathrm{KCl} / \mathrm{plant} 2 \text { times/year }\end{array}$ \\
\hline 5 & Weeding & Uncertain & 2 times/year \\
\hline 6 & Pest and disease control & Not done & per attack level \\
\hline 7 & Tapping frequency & Every day & Every 2 days \\
\hline 8 & Age is starting to tap & $6-7$ year & 4 years \\
\hline
\end{tabular}

Source : Afrizon,et.al, 2015

\subsection{Rubber conversion to oil palm in Batik Nau Sub district}

In the last 10 years, the price of rubber at the farm level has fallen very drastically, with prices of only Rp 4500 - Rp 5000 / kg. This condition causes farmers to be less enthusiastic about managing their rubber plants. Based on information obtained in Air Manganyau Village, the main factor causing conversion is economic factors, according to information provided by officersextension agent of Batik Nau. The low price of rubber makes it difficult for farmers to find tappers. With a 50:50 profit sharing, low rubber yields, and low selling price, the tapper can only earn 150-200 thousand rupiah per week from one hectare of rubber land. The labor workers in Air Manganyau Village prefer other jobs such as being laborers for harvesting oil palm or working in oil palm processing factories or oil palm plantations located in LubukBanyau, Padang Jaya District, which is located adjacent to Air Manganyau Village.

Many rubber plantations in Batik Nau District have been converted into oil palm, especially with the oil palm Replanting Program from the center in the last 2 years. In the first stage of replanting, an area of 418 ha had been implemented in three villages (Saban Jaya, Pagar Ruyung, and Durian Amparan). Saban Jaya Village has replicated 188 ha by involving 99 families and of this area, 50 hectares come from rubber plantations. Converting rubber to oil palm is estimated to be more profitable for farmers in the future. This is because the price of oil palm fresh fruit bunch (FFB) continues to increase (the current FFB price is Rp. 1,800/kg) and FFB harvesting does not need to be done every day so that farmers can save labor. As a result of the conversion, the area of the rubber plantation was getting narrower according to the farmers' ability to tap due to labor problems that did not benefit the plantation owner.

According to [13] the reason for rubber farmers to change their function to become oil palm farmers is because work as rubber farmers is carried out every day while the price is cheap so that the farmers' income is not sufficient to meet economic needs. Meanwhile, oil palm work is only once every two weeks, the price is more expensive than rubber and sufficient to meet daily needs. Changing the function of rubber farmers to oil palm farmers has a positive impact on the welfare of rubber farmer families, their income increases, their jobs are lighter, there is an increase in assets owned, and the family feels more prosperous than before. There are 2 patterns of conversion of rubber plantations to oil palm which are categorize as direct and gradual pattern (Table 3). 
Table 3. The Patterns of rubber conversion into oil palm in Batik Nau Sub district

\begin{tabular}{|c|c|c|c|}
\hline No & Description & Direct pattern & Gradual Pattern \\
\hline 1 & The convertingperformer & Farmers, owners of capital & Farmers \\
\hline 2 & Time of conversion & All at once & $\begin{array}{c}\text { According to ability } \\
\text { (capital, labor) }\end{array}$ \\
\hline 3 & Use of labor & Outside the family & In the family \\
\hline 4 & Capital requirements & High & Low \\
\hline 5 & Conversion process & Fast (in 1 year) & Slow (between 3-5 years) \\
\hline
\end{tabular}

\subsubsection{Direct conversion pattern}

The direct conversion pattern was carried out by farmers using the oil palm replanting program. This program has been implemented since 2019. Farmers who wish to convert their rubber plantations to oil palm have registered to become replanting participants. The replanting fee of 33 million rupiahs per hectare is very helpful for farmers in converting rubber to oil palm at once. The direct pattern is carried out by the owner of the capital by buying rubber land from the community. Conversion is carried out by buyers of rubber plantation lands from outside the village who convert them into oil palm. Based on data obtained from 1,600 hectares of rubber plantation land in Air Manganyau Village, around 320 hectares or $20 \%$ have been converted into oil palm by buyers from outside the village (owners of capital).
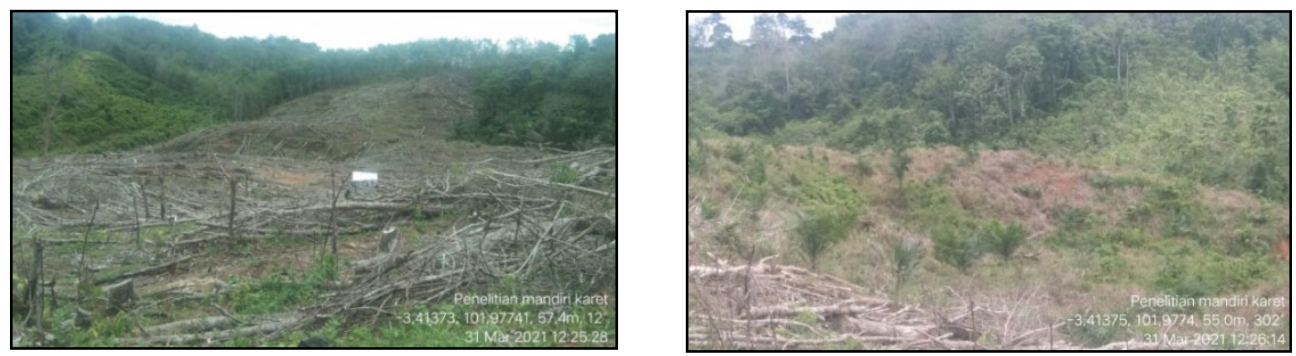

Fig. 3. The pattern of direct conversion of rubber to oil palm

\subsubsection{Gradual conversion pattern}

Gradual pattern adapted to plant conditions. Palm seedlings are obtained from buying sprouts and then seeded in polybags, buying ready-to-plant seeds and some are taking seeds that fall under the palm trees and seed them in polybag The conversion carried out by farmers independently is slowly by replacing rubber plants with oil palm. Farmers with limited capital convert by cutting down any rubber stems to be replaced with oil palm plants gradually according to the farmer's capital capacity. This causes farmers not to lose income from their rubber plants. 

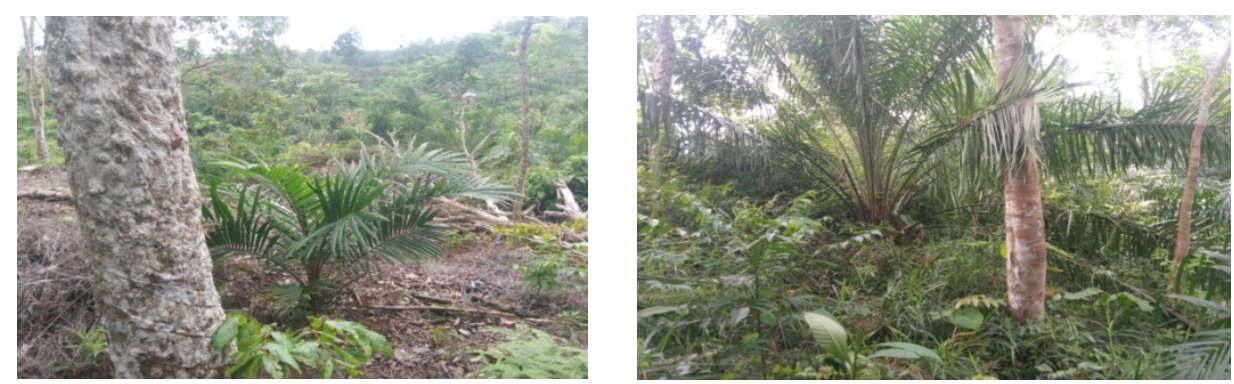

Fig. 4. The pattern of gradual conversion from rubber to oil palm

\subsection{Cause of conversion}

\subsubsection{The cheap price of rubber}

Land conversion is strongly influenced by commodity price factors [14,15]. Factors causing the conversion based on information obtained in Air Manganyau Village were the economic factors, confirmed according to information provided by extension agent officers. The low price of rubber makes it difficult for farmers to find tappers. With a 50:50 profit sharing, low rubber yields, and low selling price, workers can only earn 150-200 thousand rupiahs per week from one hectare of rubber land. Labor workers in Air Manganyau Village prefer other jobs such as being laborers for harvesting oil palm or working in palm oil processing factories or oil palm plantations in Lubuk Banyau Village, Padang Jaya Subdistrict, which is located adjacent to Air Manganyau Village. The volatile price fluctuation and tends to decrease is the reason why farmers convert rubber to oil palm.Farmers who convert crops consider that oil palm is more profitable than rubber because rubber prices tend to decline $[16,17]$. The decline in rubber prices started in 2014 from the price of Rp. 6,909/kg down to Rp. 4,847/ kg.

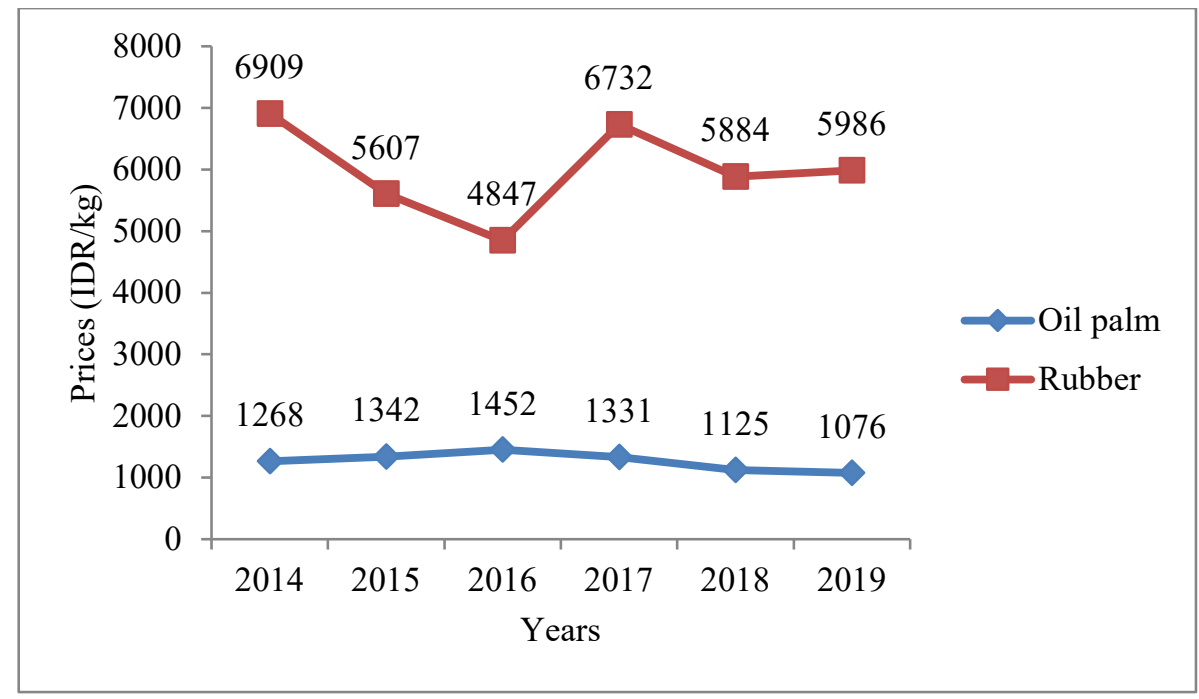

Source: BPS Statistics of Bengkulu Province

Fig. 5. Comparative data on rubber and oil palm prices (2014-2019) 


\subsubsection{Use of labor}

The ability of the workforce in the family ( 1 rubber farmer) is only able to tap a maximum of 1 hectare of rubber. If more than 1 hectare of rubber farmers are not able to do the tapping themselves because in one day the ability to tap is only 2-3 hours. Therefore, if the farmer owns more than 1 hectare of land, he needs labor from outside the family. According to [17] the time needed to tap rubber takes 2-3 days while harvesting oil palm takes 1-2 days. Harvesting oil palm is less than the time required for rubber tapping. If less time is needed with more production results, this is more profitable because it reduces the cost of the labor load [18]. Finding labor to tap is difficult because there is competition with labor for harvesting oil palm FFB. The daily wage for labor in Batik Nau Subdistrict is Rp. 120,000,per day. The wage for a rubber tapper in one day is only around Rp. 50.000,- per day.

The conditions faced by rubber farmers are more profitable if they do it themselves in a limited area, causing farmers who have a rubber plantation area of more than 1 hectare to tend to convert into oil palm plantations because it is more profitable. Therefore, it is suggested to the stakeholders that the development of the smallholder rubber plantation program should be adjusted to the availability of labor in the farmer's family.

\section{Conclusions}

There are 2 patterns of conversion of rubber to oil palm, namely direct and gradual patterns. The direct pattern is carried out by farmers through the replanting program and capital owners from outside the village. Meanwhile, the gradual pattern is carried out by the farmers themselves. The cause of conversion is the low price of rubber and the ability of farmers to cultivate rubber plantations. Limited labor is the main factor for farmers converting rubber to oil palm.

\section{References}

1. Afrizon, D. Sugandi, U.P. Astuti, Karakteristik Petani Karet Dan Produktifitas Beberapa Klon Unggul Di Provinsi Bengkulu. Prosiding Seminar Nasional Membangun Kedaulatan Pangan yang Berkelanjutan. BBP2TP., (2015)

2. A.F. Sunartomo, Agriekonomika, 4, 2 (2015)

3. U.P. Astuti, W. Wibawa, A. Ishak. Prosiding Seminar Nasional Budidaya Pertanian. Urgensi dan Strategi Pengendalian Alih Fungsi Lahan Pertanian. ISBN 978-602-19247$0-9$

4. R. Anggari, Zulfan, Husaini, Jurnal Ilmiah Mahasiswa Pendidikan Sejarah, 1, 1 (2016)

5. A. Setiawan, H. Purwadio, Jurnal Teknik Pomits, 2, 3(2013)

6. S.I. Hidayat, L. L. Rofiqoh, SEA, 9, 1 (2020)

7. Z.S. Putri, EKO-REGIONAL, 10, 1 (2015)

8. A. Saputra, Sosio Ekonomika Bisnis, 16, 2 (2013)

9. S. Harahap, N.D. Senjawati, S. Hamidah. Analisis Daya Saing Dan Daya Tarik Konversi Tanaman Karet Menjadi Kelapa Sawit di Kebun Batang Toru PT Perkebunan Nusantara III. Prosiding Seminar Nasional "Inovasi Pangan Lokal Untuk Mendukung Ketahanan Pangan” Universitas Mercu Buana Yogyakarta, ISSN: 2656-6796, (2018)

10. BPS Statistics of Bengkulu Province, Provinsi Bengkulu Dalam Angka, Bengkulu (2020)

11. Dinas Perkebunan Kabupaten Bengkulu Utara, Laporan Kegiatan Tahunan (2020)

12. BPS Statisticsof North Bengkulu Regency, Batik Nau Dalam Angka (2020)

13. I. Boerhendhy, K. Amypalupy, Jurnal Litbang Pertanian, 30, 1 (2011)

14. K. Mustofa, Jurnal Al Qardh, 5, 1(2020) 
15. E.M. Sari, Biolearning Journal, 7, 2 (2020)

16. Rusnani, UNES Journal of Scientech Research, 3, 2 (2018)

17. A. Saputra, D. S. Nurchaini, Journal of Agribusiness and Local Wisdom (JALOW), 3, 2 (2020)

18. A.Y.P. Hasibuan, Khairunnisyah, D. Hendrawan, AGRILAND Jurnal Ilmu Pertanian, 8, $2(2021)$ 